\title{
Stable isotope and trace element investigation of two contemporaneous annually-laminated stalagmites from northeastern China surrounding the " 8.2 ka event"
}

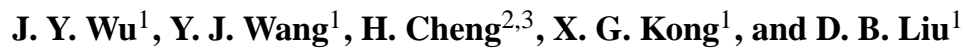 \\ ${ }^{1}$ College of Geography Science, Nanjing Normal University, Nanjing 210097, China \\ ${ }^{2}$ Institute of Global Environment Change, Xi' an Jiaotong University, Xi' an 710049, China \\ ${ }^{3}$ Department of Geology and Geophysics, University of Minnesota, Minneapolis, Minnesota 55455, USA
}

Correspondence to: Y. J. Wang (yjwang@njnu.edu.cn)

Received: 28 March 2012 - Published in Clim. Past Discuss.: 3 May 2012

Revised: 22 August 2012 - Accepted: 30 August 2012 - Published: 10 October 2012

\begin{abstract}
The prominent " $8.2 \mathrm{ka}$ event" was well documented in the Greenland ice cores. It remains unclear, however, about its duration, structure and forcing mechanism at low- to mid-latitude regions. Here we use the physical and geochemical data of stalagmites from the Nuanhe Cave in Liaoning Province, northeastern China, to reconstruct a detailed history of East Asian monsoons covering the entire duration of the event. High-resolution chronologies of two contemporaneous stalagmites, each consisting of at least $770 \mathrm{yr}$ annual growth bands, were established by calibrating and anchoring the floating band-counting ages against five highprecision ${ }^{230} \mathrm{Th}$ dates. Two oxygen isotope profiles replicate each other on annual-decadal timescales despite their difference in growth rates, indicating that the $\delta^{18} \mathrm{O}$ variability has a climatic origin largely associated with changes in the rainfall $\delta^{18} \mathrm{O}$ from the West Pacific during summer season. A signal from the " $8.2 \mathrm{ka}$ event" was faint in our $\delta^{18} \mathrm{O}$ records, not as significant as Indian monsoon dominated stalagmite $\delta^{18} \mathrm{O}$ records from Qunf in Oman and Dongge in Southern China. However, our $\delta^{13} \mathrm{C}$ and $\mathrm{Ba} / \mathrm{Ca}$ profiles, as indicators of local environmental changes, provide strong support for a climate reversal centred at $8.2 \mathrm{ka} \mathrm{BP}$, which is likely controlled by winter monsoon circulations via the westerly winds associated with North Atlantic climate. Therefore, we concluded that the winter- and summer-Asian monsoons responded independently to the high northern latitude climate.
\end{abstract}

\section{Introduction}

Holocene climate changes were unstable, during which a degradative anomaly centred at $8.2 \mathrm{ka} \mathrm{BP}$ (termed " $8.2 \mathrm{ka}$ event") was first observed in the Greenland ice cores, and then presented in various archives extending geographically to low latitudes (e.g. O'Brien et al., 1995; Alley et al., 1997; Thompson et al., 2002; Lachniet et al., 2004; Wang et al., 2005; Thomas et al., 2007; Cheng et al., 2009). In spite of being intensively studied, however, the timing, duration and structure of the $8.2 \mathrm{ka}$ event have not been well-constrained in low- and mid-latitude regions due to a paucity of highlyresolved and precisely-dated records. Morrill et al. (2003) reviewed 36 published studies relevant to the Asian monsoon (AM) and concluded that no strong evidence was found for an abrupt change in the AM at $\sim 8.2 \mathrm{ka} \mathrm{BP}$. Overall, there is little evidence for the presence of the event in the eastern part, which is not much stronger than other Holocene anomalies in the western part of Asia (Alley and Ágústsdóttir, 2005). Rohling and Pälike (2005) claimed that the " $8.2 \mathrm{ka}$ event" expressed as an anomaly superimposed on a $400 \sim 600$-yr cold/aridity episode in many of low- to mid-latitude records, which is difficult to reconcile with changes in the Greenland temperature. Using a composite of four Greenland ice core records, Thomas et al. (2007) found a small increase in $\mathrm{Ca}^{2+}$ and $\mathrm{Cl}^{-}$during the $8.2 \mathrm{ka}$ event, about $5 \%$ amplitude of that observed in the Younger Dryas. As the two proxies represent changes in low- and mid-latitude atmospheric circulation and its moisture source, it was then suggested that the large-scale 
atmospheric response was very subdued, and certainly not proportional to the local climate signal in the North Atlantic.

Therefore, it is important to explore multi-proxy archives at the same location to investigate different regional climate response to the so-called global " $8.2 \mathrm{ka}$ event", particularly winter- and summer-dominated proxies associated with a seasonal significance must be taken into account (Rohling and Pälike, 2005). For example, the greyscale from the Cariaco basin shows a short-lived enhancement of wintertime trade winds during 8.25 8.10 ka BP (Hughen et al., 1996), while the Ti percentage indicates a period of aridity between 8.40 and $7.75 \mathrm{ka}$ BP induced by southward migration of the Intertropical Convergence Zone (ITCZ) in summer (Haug et al., 2001). In the same manner, we use different proxies of stalagmites to investigate seasonal variations of climate in northeastern China, typically dominated by East Asian monsoons. In addition, annually-laminated sequences in stalagmites can be used as a valid means of ascertaining highresolution chronology (Proctor et al., 2002; Tan et al., 2003; Paulsen et al., 2003; Baker et al., 2007), comparable to treering records. This approach is crucial for determining the duration and detailed structure of the $8.2 \mathrm{ka}$ event. Here we try to use two contemporaneous annually-laminated stalagmites to develop an annually-resolved timescale.

\section{Materials and methods}

\subsection{Site setting and sample description}

Nuanhe Cave $\left(41^{\circ} 20^{\prime} \mathrm{N}, 124^{\circ} 55^{\prime} \mathrm{E}, 500 \mathrm{~m}\right.$ a.s.l. $)$ is located at Huanren County in Liaoning Province, northeastern China (Fig. 1). Present climatic condition is characterized by seasonal alternations of summer and winter monsoon circulations, which are formed as a result of thermal differences between the Asian landmass and the Pacific Ocean, and are further enhanced by the thermal and dynamic effect of the Tibetan Plateau. In the summer season, warm and humid air originating from the low latitude oceans migrates north along with the seasonal changes of planetary scale circulations, and is further driven by the east/west pressure gradient in East Asia. Warm and humid air can extend northwesterly into China's interior as far as the China-Mongolia border, leading to intensive rainfall from June through September which contributes $60 \%$ of the mean annual precipitation at the site (between $800 \mathrm{~mm}$ and $900 \mathrm{~mm}$ ). While in the winter season, dry and cold air from high latitudes is controlled by the continental high-pressure system, and propagates southward along the eastern margin of the Tibetan Plateau to form the strongest northerly dry winter monsoon (An, 2000). The East Asian Winter Monsoon (EAWM) produces a dry and cold winter season from November until February at the cave site. The seasonal Celsius temperature of this area ranges between $-13^{\circ}$ in January and $22^{\circ}$ in July (meteorological data, $1956 \sim 1991)$.

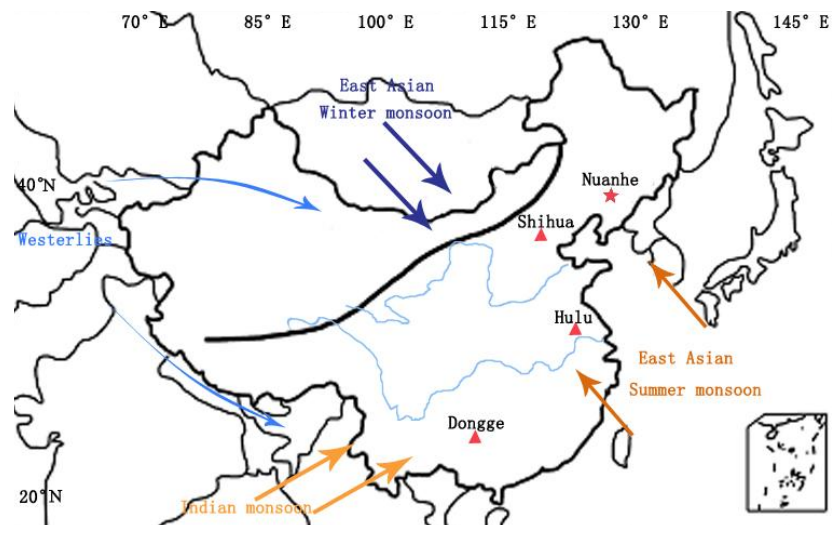

Fig. 1. Location of Nuanhe Cave. The orange arrows show different sub-systems of Asian summer monsoon, blue arrows indicate East Asian winter monsoon and westerly winds, respectively. The bold line illustrates the northern limit of summer monsoon. The red star and triangles indicate the location of Nuanhe Cave and other cave sites mentioned in this study.

The cave was developed in Ordovician limestone formation and is about $200 \mathrm{~m}$ long and $5 \sim 30 \mathrm{~m}$ in width and height. The only entrance of the cave, with a diameter less than $1 \mathrm{~m}$, exposes on the slope of a small hill. The vegetation cover consists of mixed-deciduous forest. Relative humidity in the cave is $\sim 100 \%$ and the cave temperature remains constant throughout the year, approximating an annual mean value of $6^{\circ}$ (the average of 5 measurements). Two columnarshaped stalagmites (NH6 and NH33), within a distance of $3 \mathrm{~m}$, were collected in a chamber $\left(6 \mathrm{~m}\right.$ high and $30 \mathrm{~m}^{2}$ large) of the cave, approximately $100 \mathrm{~m}$ from its entrance and about $20 \mathrm{~m}$ below the surface. Sample NH33 is $56 \mathrm{~mm}$ in length and 35 to $60 \mathrm{~mm}$ in diameter. Sample NH6 is $165 \mathrm{~mm}$ in length and 45 to $150 \mathrm{~mm}$ in diameter. When halved and polished, both samples show well-developed micro-meter-scale laminations on polished surface, being composed of typical coalescent columnar-fabric calcite crystals. Under a microscope, the thin sections exhibit densely-distributed laminations (Fig. 2), and no evidence of any hiatus exists. The lamina sequences are unclear for the top part in the two samples $(0 \sim 9.5 \mathrm{~mm}$ for NH33, $0 \sim 43 \mathrm{~mm}$ for NH6); thus, we focus on the intervals with continuously-developed laminations, i.e. at 9.5 to $56 \mathrm{~mm}$ for $\mathrm{NH} 33$, and at 43 to $88 \mathrm{~mm}$ for NH6, respectively.

\subsection{Analytical methods}

Five sub-samples were collected along the growth axis of the two stalagmites with 0.9-mm-diameter carbide dental burrs for ${ }^{230} \mathrm{Th}$ dating. The measurements were performed by inductively coupled plasma mass spectrometry (ICP-MS) on a Finnigan-MAT Element at the Department of Geology and Geophysics, University of Minnesota, USA. The procedures are similar to those described in Shen et al. (2002), with 


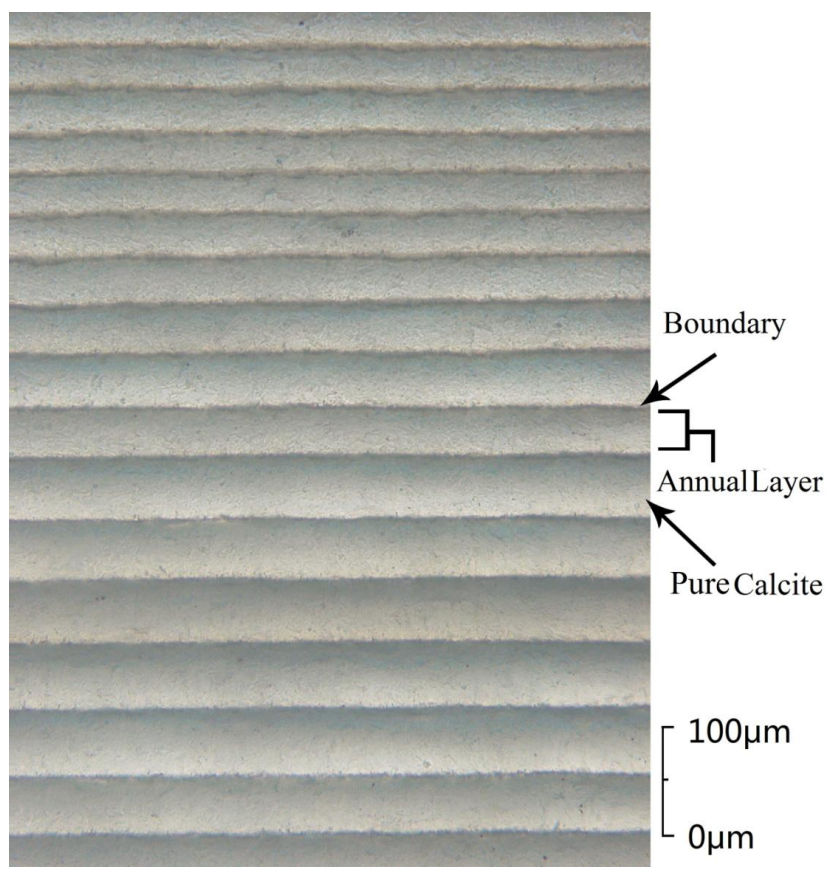

Fig. 2. Micrograph (using a $10 \times$ objective lens) showing examples of typical well-formed annual bands preserved in a small columnar stalagmite NH33.

results listed in Table 1. All dates are in stratigraphic order with typical analytical errors $(2 \sigma)$.

A total of 608 sub-samples (350 for NH33 and 258 for NH6) were collected by knife shaving along the growth axis for stable isotopic analysis. Measurement was performed with a Finnigan-MAT 253 mass spectrometer fitted with a Kiel Carbonate Device at the College of Geography Science, Nanjing Normal University. Spatial resolution varies from 0.06 to $0.2 \mathrm{~mm}$, corresponding to a temporal resolution of 1 to $15 \mathrm{yr}$. Values of $\delta^{18} \mathrm{O}$ and $\delta^{13} \mathrm{C}$ were reported relative to Vienna Pee Dee Belemnite (VPDB) and with standardization determined relative to $\operatorname{NBS} 19\left(\delta^{18} \mathrm{O}=-2.2 \%\right.$, $\delta^{13} \mathrm{C}=1.95 \%$ ). The precision of $\delta^{18} \mathrm{O}$ values is $0.06 \%$ at the $1-\sigma$ level.

Trace element analyses were performed using Avaatech XRF Core Scanner (X-ray fluorescence spectrometry), equipped with a variable optical system that enables any resolution between 10 and $0.1 \mathrm{~mm}$ at the Surficial Geochemical Laboratory, Nanjing University, China. A total of 308 and 226 elemental ratios of $\mathrm{Ba} / \mathrm{Ca}$ were obtained for $\mathrm{NH} 33$ and NH6, with an average resolution of $\sim 2 \mathrm{yr}$ and $\sim 3 \mathrm{yr}$, respectively. The two time series of $\mathrm{Ba} / \mathrm{Ca}$ do not cover the whole profile like the stable isotope data due to two reasons: (1) the presence of pre-existing dating sampling pits on the polished sections prevents laser scanning; and (2) the lower part of Sample NH33 is too small to be scanned.

Band counting was performed under an Olympus optical microscope following the procedures described in Tan

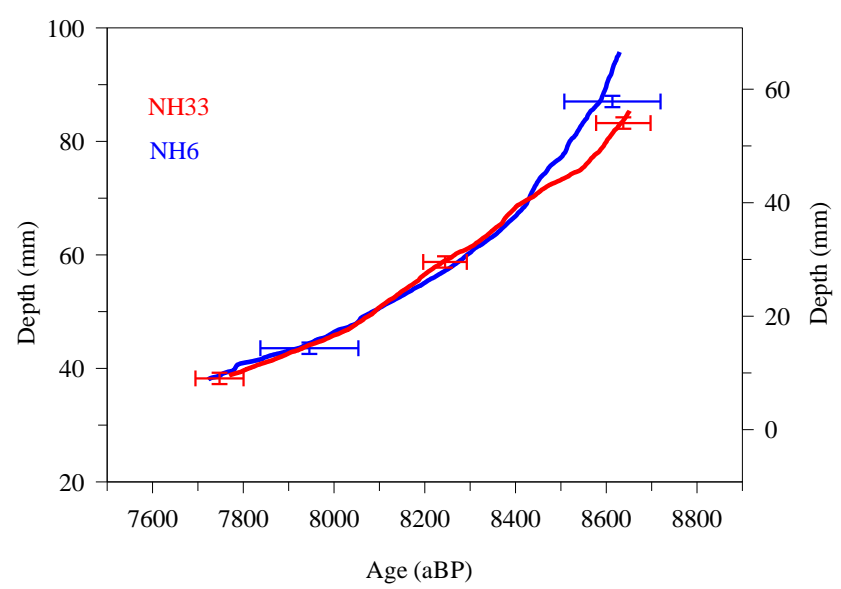

Fig. 3. Independent assessment of the annual growth band-counting chronologies for the two stalagmites using five ${ }^{230} \mathrm{Th}$ dates. Uncertainties of dating ( \pm 48 to $\pm 106 \mathrm{yr}$ ) and sampling position ( \pm 0.5 to $\pm 1 \mathrm{~mm}$ ) are represented by horizontal and vertical bar, respectively.

et al. (2003). Counts along the growth axes yielded a total of 883 bands for NH33 and 778 bands for NH6, respectively. The thickness of each band ranges from 10 to $370 \mu \mathrm{m}$, with the most between 30 and $70 \mu \mathrm{m}$. Counting uncertainty is likely larger during intervals of low growth rate. However, the annual bands in both samples show a distinct feature of lamina throughout the studied interval, so that errors of counted bands are assumed to be small, amount to \pm 10 bands for NH33 and \pm 22 bands for NH6, based on statistical error along three different tracks.

\section{Results}

\subsection{Annually-resolved chronology}

${ }^{230} \mathrm{Th}$ dates are shown in Table 1 , covering a period of $8.6 \sim 7.7 \mathrm{ka} \mathrm{BP}$ for NH33 and 8.6 $7.3 \mathrm{ka}$ BP for NH6 (relative to $1950 \mathrm{AD}$ ). Corrections for the presence of high detrital ${ }^{230} \mathrm{Th}$ as reflected by high ${ }^{232} \mathrm{Th}$ concentrations in some samples, particularly NH6 $\left(398 \sim 625 \times 10^{-12}\right.$, see Table 1), lead to a large uncertainty of the corrected ${ }^{230} \mathrm{Th}$ dates. The band-counting growth rate can be checked against the ${ }^{230}$ Th-based growth rates (Fig. 3). Our timescale for the $\delta^{18} \mathrm{O}$ was reconstructed by adjusting the floating annuallycounting growth rate to the dated one. The annuality of bands can be supported by the ${ }^{230} \mathrm{Th}$-based growth rates and consistence in annual growth rate between the two samples except for an interval of the oldest $200 \mathrm{yr}$.

The two profiles of counting-based growth rate replicate each other over a period younger than $8.42 \mathrm{ka}$ BP (Fig. 3), narrowing the uncertainty of ${ }^{230} \mathrm{Th}$ dates for Sample NH6 within \pm 50 yr. Despite the two samples showing a large difference in growth rate prior to $8.42 \mathrm{ka} \mathrm{BP}$, their $\delta^{18} \mathrm{O}$ profiles 
Table 1. ${ }^{230}$ Th dating results from stalagmite NH from Nuanhe Cave, China.

\begin{tabular}{|c|c|c|c|c|c|c|c|c|}
\hline $\begin{array}{l}\text { Sample } \\
\text { number }\end{array}$ & $\begin{array}{l}\text { Depth } \\
(\mathrm{mm})\end{array}$ & $\begin{array}{r}238 \mathrm{U} / \\
\times 10^{-9}\end{array}$ & $\begin{array}{r}{ }^{232} \mathrm{Th} / \\
\times 10^{-12}\end{array}$ & $\begin{array}{r}\delta^{234} U \\
\text { (measured) }\end{array}$ & $\begin{array}{r}{ }^{230} \mathrm{Th} /{ }^{238} \mathrm{U} \\
\text { (activity) }\end{array}$ & $\begin{array}{r}{ }^{230} \mathrm{Th} \text { Age } \\
(\mathrm{aBP}) \\
\text { (uncorrected) }\end{array}$ & $\begin{array}{r}{ }^{230} \text { Th Age } \\
(\mathrm{aBP}) \\
\text { (corrected) }\end{array}$ & $\begin{array}{r}{ }^{\delta^{234} \mathrm{U}_{0}} \\
\text { (corrected) }\end{array}$ \\
\hline NH33-2 & 9 & $102.8 \pm 0.1$ & $398 \pm 8$ & $1031 \pm 3$ & $0.1421 \pm 0.0006$ & $7862 \pm 36$ & $7748 \pm 53$ & $1054 \pm 3$ \\
\hline NH33-I & 29 & $163.4 \pm 0.3$ & $625 \pm 13$ & $1034 \pm 3$ & $0.1511 \pm 0.0005$ & $8360 \pm 30$ & $8245 \pm 48$ & $1056 \pm 3$ \\
\hline NH33-3 & 54 & $122.7 \pm 0.1$ & $482 \pm 10$ & $1005 \pm 3$ & $0.1556 \pm 0.0007$ & $8754 \pm 45$ & $8638 \pm 60$ & $1030 \pm 3$ \\
\hline NH6-43 & 43 & $114.5 \pm 0.3$ & $399 \pm 3$ & $1054.8 \pm 6.0$ & $0.14611 \pm 0.00181$ & $7995 \pm 105$ & $7946 \pm 105$ & $1078.7 \pm 6.1$ \\
\hline NH6-87 & 87 & $123.7 \pm 0.3$ & $612 \pm 4$ & $1034.0 \pm 4.8$ & $0.15665 \pm 0.00170$ & $8683 \pm 100$ & $8614 \pm 106$ & $1059.4 \pm 4.9$ \\
\hline
\end{tabular}

Errors are $2 \sigma$ analytical errors. Decay constant values are $\lambda_{230}=9.1599 \times 10^{-6} \mathrm{yr}^{-1}, \lambda_{234}=2.8263 \times 10^{-6} \mathrm{yr}^{-1}, \lambda_{238}=1.55125 \times 10^{-10} \mathrm{yr}^{-1},{ }^{234} \mathrm{U}=\left({ }^{234} \mathrm{U} /\right.$ $\left.\left.{ }^{238} \mathrm{U}\right]_{\text {activity }}-1\right) \times 1000,{ }^{234} \mathrm{U}_{\text {initial }}={ }^{234} \mathrm{U}_{\text {meaured }} \times \mathrm{e}^{234 \times T}$, corrected ${ }^{230} \mathrm{Th}$ ages assume an initial ${ }^{230} \mathrm{Th} /{ }^{232} \mathrm{Th}$ atomic ratio of $(4.4 \pm 2.2) \times 10^{-6}$. Corrected ${ }^{230} \mathrm{Th}$ ages are indicated in bold and presented in years before $1950 \mathrm{AD}$.

are well duplicated (discussed below in detail), ensuring that their uncertainty of ${ }^{230} \mathrm{Th}$ age is trivial, within $\pm 60 \mathrm{yr}$.

\subsection{Multi-proxy profiles}

$\mathrm{NH} 33 \delta^{18} \mathrm{O}$ profile at $\sim 2.5$-yr resolution varies from $-7.9 \%$ to $-10.3 \%$, with an average of $-9.0 \%$ o. NH6 $\delta^{18} \mathrm{O}$ profile at $\sim 3$-yr resolution shifts between $-8.1 \%$ and $-10.0 \%$, with an overall mean of $-9.2 \%$. No long-term trend is observed in the two profiles. A striking similarity between them $(r=0.62, n=111)$ is evident over $8.38 \sim 8.04 \mathrm{ka} \mathrm{BP}$ in terms of their decadal cycles and absolute values. Despite that $\mathrm{NH6} \delta^{18} \mathrm{O}$ values are slightly enriched $(\sim 0.2 \%$ o with respect to those of NH33 during an interval of $8.63 \sim 8.38 \mathrm{ka}$ $\mathrm{BP}$, a similar pattern between them $(r=0.15, n=70)$ is observed. A replication becomes worse $(r=0.09, n=89)$ during $8.04 \sim 7.83 \mathrm{ka}$ BP. The overall $\delta^{18} \mathrm{O}$ pattern can be roughly divided into three phases at 8.35 and $8.05 \mathrm{ka} \mathrm{BP}$, respectively, based on their mean values of $\delta^{18} \mathrm{O}$.

$\delta^{13} \mathrm{C}$ values range from $-9.9 \%$ to $-11.9 \%$, with an average of $-10.7 \%$ for $\mathrm{NH} 33$; and from $-9.7 \%$ o to $-12.1 \%$, with an average of $-10.8 \%$ ofor NH6. The two $\delta^{13} \mathrm{C}$ records replicate each other prior to $8.2 \mathrm{ka} \mathrm{BP}$, particularly a similar increasing trend between $8.42 \sim 8.20 \mathrm{ka} \mathrm{BP}$. After that time, the two records have some discrepancies with a deviation of $0.57 \%$, suggesting that other processes during the stalagmite growth overweighted climatic and environmental signal.

The values of $\mathrm{Ba} / \mathrm{Ca}$ ratio vary between $2.8 \times 10^{-3}$ and $10.4 \times 10^{-3}$, with a mean of $5.5 \times 10^{-3}$ for NH33, and between $1.9 \times 10^{-3}$ and $9.8 \times 10^{-3}$, with a mean of $5.6 \times 10^{-3}$ for NH6. Changes of two $\mathrm{Ba} / \mathrm{Ca}$ profiles, with a similar trend over the contemporaneous period, show some difference after $8.06 \mathrm{ka} \mathrm{BP}$ in terms of their absolute values.

Annual layer thickness (ALT) values for the two samples range from 10 to $370 \mu \mathrm{m}$, centred on $20 \sim 70 \mu \mathrm{m}$. Variation of ALT is relative small, ranging from 20 to $210 \mu \mathrm{m}$ for Sample $\mathrm{NH} 33$; and it is large, ranging from 10 to $370 \mu \mathrm{m}$ for Sample NH6. However, both records show a similar decreasing trend from 8.6 to $7.6 \mathrm{ka} \mathrm{BP}$, with a large deviation prior to $8.4 \mathrm{ka}$ BP. This suggests that the cave environment changed significantly since that time, consistent with the inference from the $\delta^{13} \mathrm{C}$ data.

\section{Discussions}

\subsection{Interpretation of the stalagmite proxies}

\subsubsection{Calcite $\delta^{18} \mathrm{O}$ as indicative of summer monsoon intensity}

The use of stalagmite $\delta^{18} \mathrm{O}$ as a palaeoclimate proxy requires evaluation of the veracity of the records. In principle, the speleothem $\delta^{18} \mathrm{O}$ signal is influenced by (i) the $\delta^{18} \mathrm{O}$ of the drip water, (ii) the temperature in the cave, and (iii) effects of kinetic isotope fractionation (Mickler et al., 2004, 2006). In the case of kinetic fractionation, a relationship between $\delta^{18} \mathrm{O}_{\text {drip }}$ and $\delta^{18} \mathrm{O}_{\text {calcite }}$, the description requires more complex models (Dreybrodt, 2008; Scholz et al., 2009). An effective test for isotopic equilibrium is the replication of contemporaneous stalagmite $\delta^{18} \mathrm{O}$ records from the same cave (Dorale and Liu, 2009). The best replicated part of the contemporaneous interval in our records suggests that the kinetic processes are either absent or their net effect on speleothem calcite $\delta^{18} \mathrm{O}$ must have been the same. The $\delta^{18} \mathrm{O}$ values from Nuanhe Cave oscillate within an amplitude of $2 \%$. Due to the small temperature-dependent fractionation between the calcite and water $\left(-0.23 \% /^{\circ}\right.$, O'Neil et al., 1969), $\delta^{18} \mathrm{O}$ variations of this magnitude must be dominated by changes in the drip-water $\delta^{18} \mathrm{O}$, i.e. the amount-weighted $\delta^{18} \mathrm{O}$ of the precipitation.

The meteorological data from the nearby Benxi Station (Source from http://isohis.iaea.org, 1956 $2000 \mathrm{AD}$ ) show that rainfall amounts during the summer seasons (June $\sim$ September) make up $60 \% \sim 85 \%$ of annual totals, and display a strong correlation with the annual totals (correlative coefficient $r=0.903$ ) for the past $50 \mathrm{yr}$. This implies that the amount of winter precipitation remained relatively stable during this period. If taking the evaporation into consideration, summer monsoon contributes more to the annual 
amount of cave dripping water. A large evaporation occurs between April and June, while relative humidity reaches the maximum during July to September. Due to the high humidity during the summer monsoon period (possibly including densely covered vegetation), evaporation is significantly reduced. Thus summer monsoonal rainfall contributes the bulk of the annual amount of cave drip water. Therefore, shifts in our $\delta^{18} \mathrm{O}$ largely reflect changes in $\delta^{18} \mathrm{O}$ values of meteoric precipitation as previously interpreted for Hulu and Sanbao $\delta^{18} \mathrm{O}$ records (Wang et al., 2001, 2008; Cheng et al., 2006, 2009). The variations we observed here likely relate to the proportion of summer monsoon (low $\delta^{18} \mathrm{O}$ ) rainfall in the annual total (Cheng et al., 2009), sometimes referred to as "monsoon intensity".

\subsubsection{Local environmental changes}

The carbon isotopic variations at short timescales with which we are concerned here may arise from both temperaturedriven changes in the soil biogenic production (plant root respiration and microbial activity of the soil and the epikarst zone) and humidity-driven changes in the extent of degassing of drip waters. A warmer climate with adequate soil moisture triggers the microbial activity in the soil above the cave and allows vegetation to develop, producing $\mathrm{CO}_{2}$ depleted in ${ }^{13} \mathrm{C}$ and finally leading to a decrease in the speleothem $\delta^{13} \mathrm{C}$. Conversely, a colder climate induces the reduction of plant and soil activity, the $\delta^{13} \mathrm{C}$ of the dissolved $\mathrm{CO}_{2}$ much less influenced by biogenic $\mathrm{CO}_{2}$ and more by atmospheric $\mathrm{CO}_{2}$, leading to an increase in the speleothem $\delta^{13} \mathrm{C}$ (Genty et al., 2006). The stalagmite $\delta^{13} \mathrm{C}$ is regulated by an additional effect within the cave system, the extent of $\mathrm{CO}_{2}$ degassing prior to stalagmite precipitation (prior calcite precipitation, $\mathrm{PCP}$ ). In general, a high PCP occurs under arid conditions, leading to a relative positive $\delta^{13} \mathrm{C}$ value in calcite (Fairchild et al., 2006). This contribution will be evaluated by a comparison of $\delta^{13} \mathrm{C}$ and trace element data.

$\mathrm{Ba} / \mathrm{Ca}$ ratio provides a valid means for understanding past changes of cave environment (e.g. Treble et al., 2003; Desmarchelier et al., 2006; Johnson et al., 2006). Ba is predominantly sourced in soil minerals and dust (Ayalon et al., 1999). Ba/Ca ratios are expected to be higher during drier periods due to PCP in soils. If the PCP is important, it will produce calcite relatively enriched in both ${ }^{13} \mathrm{C}$ and barium (Fairchild and Treble, 2009). However, the opposite of this is observed in our stalagmites, in which $\delta^{13} \mathrm{C}$ is inversely correlated with barium concentration. From this, it is apparent that the variation common to the $\delta^{13} \mathrm{C}$ and barium records cannot be explained in terms of PCP, and that $\delta^{13} \mathrm{C}$ changes can only be dominated by this effect if barium is forced by a closely related environmental factor. Barium is considered as a rather immobile element in soils due to a high cation exchange selectivity for $\mathrm{Ba}^{2+}$ (McBride and Homenauth, 1994). An increased $\mathrm{Ba}^{2+}$ concentration could reflect increased leaching of soil cations by more concentrated carbonic acid (Hellstrom and McCulloch, 2000). Under these conditions, $\mathrm{Ba} / \mathrm{Ca}$ ratios may increase when the climate is warm (increase biological activity), and vice versa. The anticorrelation between our $\mathrm{Ba} / \mathrm{Ca}$ ratios and $\delta^{13} \mathrm{C}$ records suggests that the climate degradation is mostly due to temperature decrease rather than precipitation decrease, such as observed from 8.42 to $8.2 \mathrm{ka} \mathrm{BP}$ in our record.

Changes in growth rate (annually laminated sequence) can provide another clue to climatic and environmental condition at cave site, for example, annual changes in local rainfall (Burns et al., 2002). The fabric feature of annual layer in our cave bears a resemblance to those from several other caves in China dominantly controlled by seasonal variations in temperature and rainfall (Tan et al., 2003; Wu et al., 2006), which can be summarized as follows. (i) A clear division between bands exhibits a dark stripe under transmission light and luminescence light under UV excitation, indicating a higher content of organic matter and dust input between bands; (ii) the bands were mainly composed of one phase, i.e. columnar-fabric crystals of calcite minerals perpendicular to the growing substrate; and (iii) variation of ALT is relatively small, ALT usually less than $1 \mathrm{~mm}$, focusing on $30 \sim 200 \mu \mathrm{m}$. The formation of these kinds of layers is closely related to the monsoon climate, i.e. distinctly seasonal contrast of precipitation and temperature (Tan et al., 2006; Baker et al., 2008). At our cave site, $60 \%$ of annual precipitation falls between June to September and the period of seasonally frozen ground lasts about 4 months (December to March), causing drip cessation. Thus, impurities including dust and organic matter at ceased-growing boundary are beneficial in creating new crystallization cores of calcite, leading to an apparent division between bands.

If the growth axis keeps perpendicular to the growth surface, as we observed from the two samples, it can be implied that the flow path remains unchanged during the entire growth period. As a result, changes in growth rate likely depend on external environmental influences. Two factors should be considered. One is carbonic acid concentration in cave dripwater, which has a strong influence on speleothem growth rate and is linked to carbon dioxide concentration in the soils above (Dulinski and Rozanski, 1990). This kind variance often causes a remarkable change in ALT (Fairchild et al., 2006). In Sample NH6, differences of ALT in adjacent layers reach as much as 20 times, and have a remarkable boundary at $\sim 8.4 \mathrm{ka} \mathrm{BP}$. The corresponding $\delta^{13} \mathrm{C}$ profiles suggest that high soil $\mathrm{CO}_{2}$ concentration may dissolve in dripwater prior to $\sim 8.42 \mathrm{ka} \mathrm{BP}$, exerting a strong influence on stalagmite growth rate. Another factor is variation of seepage amount from year to year, broadly responding to local precipitation, which provides the total amount of annual precipitates for stalagmite growth. If controlled only by this factor, the ALT is basically characterised by gradual changes between layers and with small amplitude. Thus, the ALT can indicate the variations of the precipitation if other condition remains unchanged (Baker et al., 1993, 1998; Genty and 


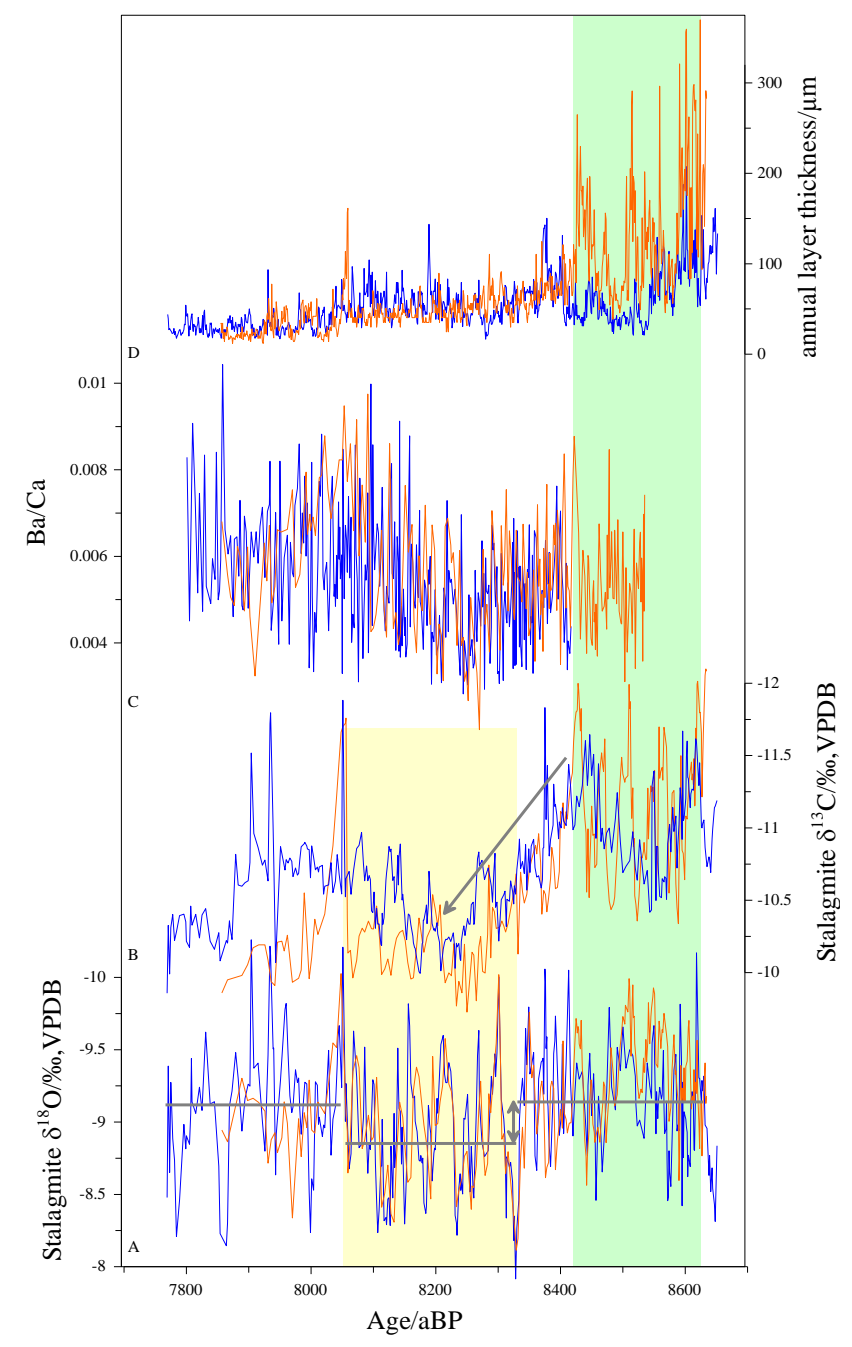

Fig. 4. Comparison of multi-proxy records between two stalagmites (NH33-blue curves and NH6-orange curves). (A) $\delta^{18} \mathrm{O}$ records, the gray lines designate average values of $\delta^{18} \mathrm{O}$ in 3 phases; (B) $\delta^{13} \mathrm{C}$ records, the gray arrow illustrates the same trend between two $\delta^{13} \mathrm{C}$ records; (C) $\mathrm{Ba} / \mathrm{Ca}$ ratio records; (D) annual layer thickness records.

Quinif, 1996). For the samples from Nuanhe Cave, an infiltration control of ALT probably occurred after $8.42 \mathrm{ka} \mathrm{BP}$.

In summary, the ALT profiles in the Nuanhe Cave suggest that the two factors of $p \mathrm{CO}_{2}$ and yearly seeping-water amount may play an important role in changing ALT signal alternatively or at the same time. During the infiltrationdominated period of $8.4 \sim 7.9 \mathrm{ka} \mathrm{BP}$, the two ALT profiles also show remarkable differences (Fig. 4), implying that the two factors existed at the same time or that more factors were involved. Thus, our ALT records should be calibrated if used as a valid climate indicator.

Kinetic fractionation of isotope partition exists between water and rock if relationship between calcite $\delta^{18} \mathrm{O}$ and ALT is significant (Mickler et al., 2004). Statistical analysis shows no significant correlation between ALT and oxygen isotope
( $r=0.02, n=883$ ) for NH33, suggesting little kinetic effect on $\delta^{18}$ O. For Sample NH6, a weak negative correlation $(r=-0.3, n=778)$ suggests a small kinetic effect on $\delta^{18} \mathrm{O}$. In particular, at the $p \mathrm{CO}_{2}$-dominated period of the oldest $200 \mathrm{yr}$, the kinetic effect would be larger because of a negative shift of $0.5 \%$ o compared with that of NH33.

\subsection{Monsoonal 8.2 ka event}

Speleothem $\delta^{18} \mathrm{O}$ records from Qunf (Fleitmann et al., 2003) and Dongge Cave (Wang et al., 2005) indicate an Asian Monsoon (AM) failure roughly between 8.6 and $8.1 \mathrm{ka}$ BP. In addition, a well-dated census of African summer-monsoonfed lakes (Gasse, 2000) illustrates a well-defined reduction in monsoon intensity or penetration between approximately 8.5 and $7.8 \mathrm{ka} \mathrm{BP}$. These anomalies are attributed to the " $8.2 \mathrm{ka}$ event" itself, but distinctly different from the typical of $8.2 \mathrm{ka}$ event recorded in Greenland ice cores. The $8.2 \mathrm{ka}$ event at Greenland was estimated to be about the magnitude of cooling to $6 \pm 2^{\circ}$ (Alley et al., 1997), with a total duration of $160.5 \mathrm{yr}$ and centred peak of $69 \mathrm{yr}$ (Thomas et al., 2007). At present there has been no strong evidence for the monsoonal $8.2 \mathrm{ka}$ event equivalent to that at Greenland, including latterly re-dated cave records in Indian and East Asian regions (Cheng et al., 2009). In addition, the monsoon anomalies do not show abrupt changes at the onset and termination, appearing to be superimposed on a longer-term monsoon reduction (Rohling and Pälike, 2005).

Despite our $\delta^{18} \mathrm{O}$ records showing a significant difference from the previously published cave data from the Asian continent (Fleitmann et al., 2003; Wang et al., 2005; Cheng et al., 2009), a similar feature among the records can be summarized as follows (see Fig. 5). Firstly, a reduction monsoon period lasted two or three centuries in the cave $\delta^{18} \mathrm{O}$ records at $\sim 8.2 \mathrm{ka} \mathrm{BP}$, a duration that is well estimated to be $300 \mathrm{yr}$ in our new records. Secondly, a trend of monsoon weakening is not so significant as recorded at Greenland, particularly muted in the Nuanhe $\delta^{18} \mathrm{O}$ records (with a mean value of $0.3 \%$ in amplitude). Thirdly, the re-dated records show an abrupt change at $8.1 \mathrm{ka}$ BP (Cheng et al., 2009); the corresponding change in the new records displays a $60-\mathrm{yr}$ transition (Fig. 5). A likely interpretation for the significant difference between the new and Dongge/Qunf records is that the cave sites are situated in the East Asian and Indian monsoon, or subtropical and tropical monsoon-dominated regions, respectively. On the basis of a simulated result from Pausata et al. (2011), monsoon precipitation over the northern Indian Ocean and subcontinent was directly linked to changes in North Atlantic sea-ice extent during the Heinrich Event 1. As a consequence, vapor transported from the northern Indian basin into China, both directly and indirectly through recycling over the India subcontinent, had a heavier $\delta^{18} \mathrm{O}$ composition. At present, water vapors from Indian Ocean transport as far as $25^{\circ} \mathrm{N}$, including middle and lower reaches of Yangtze River, but do not reach the northeastern China where 


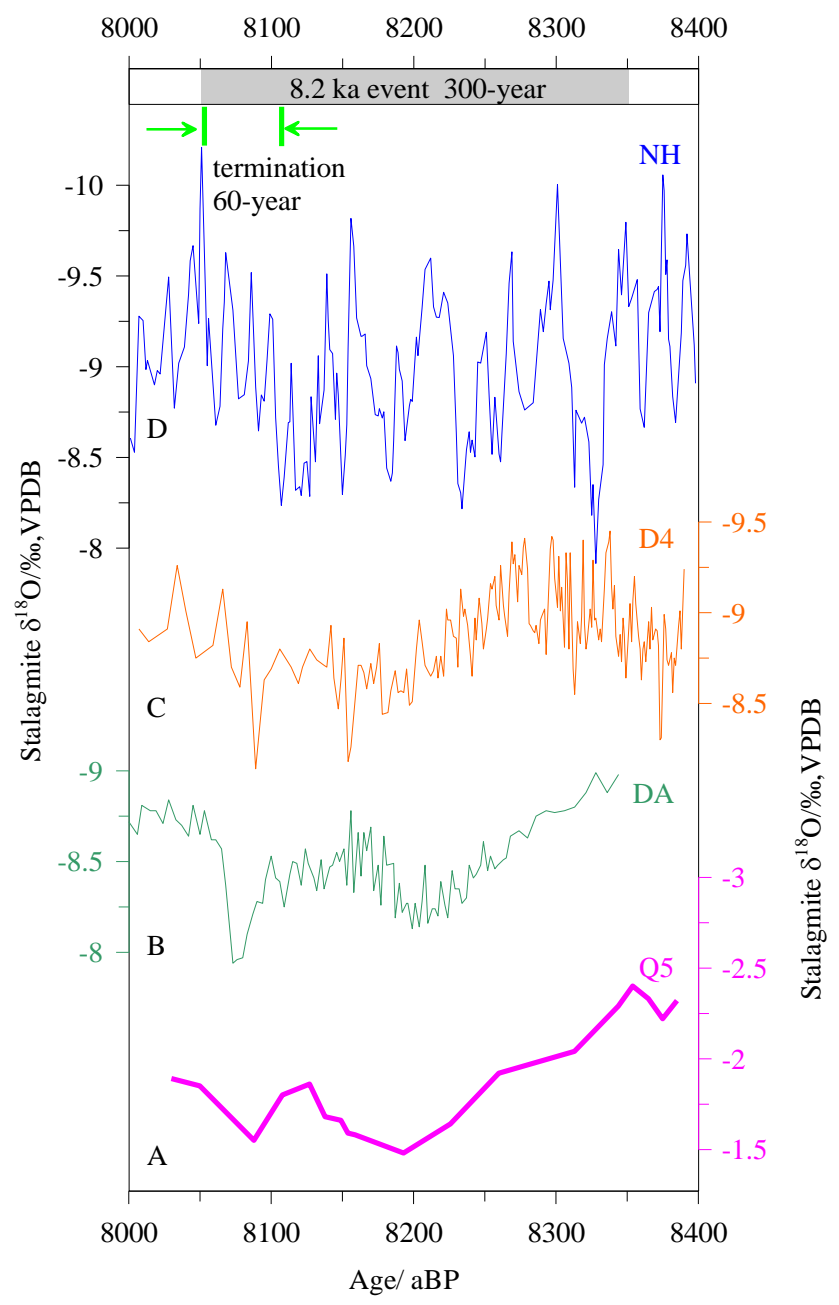

Fig. 5. $\delta^{18} \mathrm{O}$ time series over $8.2 \mathrm{ka}$ event from stalagmites. (A) Q5, Qunf Cave, Oman; (B) DA, Dongge Cave, China; (C) D4, Dongge Cave, China; (D) NH33, Nuanhe Cave, China. Q5, DA and D4 records were re-dated by Cheng et al. (2009). Gray bar indicates the broadly consistent duration of the $8.2 \mathrm{ka}$ event from all monsoon records. The end of the $8.2 \mathrm{ka}$ event in $\mathrm{NH} 33 \delta^{18} \mathrm{O}$ lasts about $60 \mathrm{yr}$.

the Nuanhe Cave is situated. This could explain why Dongge and Qunf records have a profound effect of the $8.2 \mathrm{ka}$ event. For the region typically influenced by the EASM, the blocking highs in mid- and high-latitudes of Eurasian continents and the subtropical high over the western Pacific play a more important role which is quite different from the condition for the Indian monsoon (Ding and Chan, 2005). In particular, different sources of water vapor from the Northwest Pacific and from South China Sea contribute to the EASM precipitation and its $\delta^{18} \mathrm{O}$, leading to the mixed vapor signal of highand low-Pacific at the $8.2 \mathrm{ka}$.

For a detailed comparison with $\delta^{18} \mathrm{O}$ from the GISP2 ice core, here we selected $\mathrm{NH} 33 \delta^{18} \mathrm{O}, \delta^{13} \mathrm{C}$ and $\mathrm{Ba} / \mathrm{Ca}$ records with higher resolution and without any impact from growth rate (Fig. 6). The $\mathrm{NH} 33 \delta^{13} \mathrm{C}$ record shows a climatically deteriorated trend from 8.42 to $8.20 \mathrm{ka}$ BP. This deteriorated trend is similar to those in the re-dated Dongge/Qunf records (Fig. 5), but $\sim 80 \mathrm{yr}$ longer. The duration of $8.2 \mathrm{ka}$ event in GISP2 (Stuiver and Grootes, 2000) was estimated $\sim 170 \mathrm{yr}$ and the cold period lasts $\sim 70 \mathrm{yr}$. The central event is asymmetrical in shape with considerable decadal variability in the record, as shown by the presence of a relatively warm spike at around $8.2 \mathrm{ka} \mathrm{BP}$. The stalagmite $\delta^{13} \mathrm{C}$ time series exhibit a cold climate during the corresponding inter$\operatorname{val}(8.29 \sim 8.10 \mathrm{ka} \mathrm{BP})$, agreeing well with that at Greenland. In fact, our $\mathrm{Ba} / \mathrm{Ca}$ record bears a remarkable similarity to the $8.2 \mathrm{ka}$ event recorded in the GISP2 ice core in terms of its timing, duration and structure (Fig. 6).

The discrepancies of the analogous event between regional climate proxy of $\delta^{18} \mathrm{O}$ and local environmental proxies $\left(\delta^{13} \mathrm{C}\right.$ and $\mathrm{Ba} / \mathrm{Ca}$ ) suggest different seasonal responses at the cave site to the high-latitude forcing, with a weak anomaly in a summer-dominated $\delta^{18} \mathrm{O}$ proxy and a strong response in winter-dominated proxies of $\delta^{13} \mathrm{C}$ and $\mathrm{Ba} / \mathrm{Ca}$. Atlantic Meridional Overturning Circulation (AMOC) is a driver of abrupt change in the EAM, and the northern westerlies play a role in transmitting this signal from the North Atlantic to the Asian monsoon regions (Sun et al., 2012). Both geological evidence and modelling results suggest that rapid climate change in the North Atlantic region can result in variability in the strength and position of the westerly jet, influencing Northern Hemisphere climate, including East Asia (Yanase and Abe-Ouchi, 2007; Wu et al., 2008; Nagashima et al., 2011). As AMOC slows, global northward ocean heat transport is reduced at all latitudes, including a $60 \%$ reduction north of $\sim 40^{\circ} \mathrm{N}$ at which our cave locates. Consequently, temperatures in the Northern Hemisphere decrease, with the largest cooling during the winter associated with areas of seaice expansion in both the North Pacific and North Atlantic. The increase in the meridional (latitudinal) temperature gradient leads to stronger westerly winds in the mid-latitudes and strengthened winter wind speed above the northwestern China (Sun et al., 2012). Our $\delta^{13} \mathrm{C}$ and $\mathrm{Ba} / \mathrm{Ca}$ records reflect a deteriorated climate initiated at $8.42 \mathrm{ka} \mathrm{BP}$, agreeing well with the timing of the draining of glacial lakes Agassiz and Ojibway through the Hudson Bay into the North Atlantic (8.42 \pm 0.30 ka BP; Barber et al., 1999; Kleiven et al., 2008; Lajeunesse and St-Onge, 2008). The culminated episode centred at $\sim 8.20 \mathrm{ka} \mathrm{BP}$ is very consistent with the timing, duration and structure of the $8.2 \mathrm{ka}$ event in the GISP2 record. This supports a strong coupling of EAWM and North Atlantic climate. A change in winter monsoon circulation is a fast-response variable to the high-latitude climate via atmospheric circulations. This tele-connection should be more direct, hence leading to a good match of Greenland temperature and the cave $\mathrm{Ba} / \mathrm{Ca}$ and $\delta^{13} \mathrm{C}$.

Cooling in the North Atlantic associated with the reduction of the AMOC causes a southward shift of the Intertropical Convergence Zone, thus a weakening of the EASM (Zhang and Delworth, 2005). However, the weak response of the 


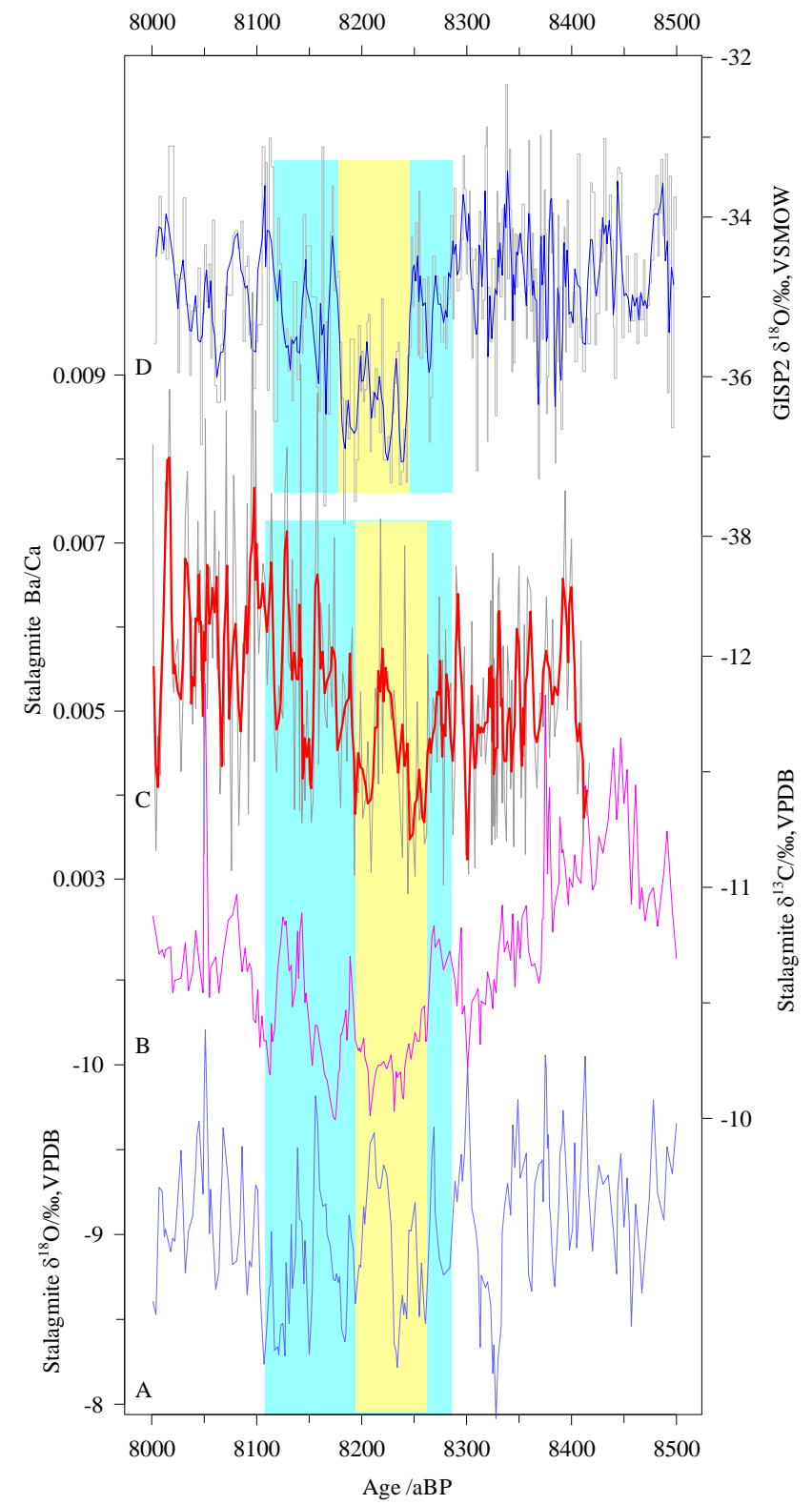

Fig. 6. Detailed comparison of multi-proxy records from stalagmite $\mathrm{NH} 33-\delta^{18} \mathrm{O}(\mathbf{A}) ; \delta^{13} \mathrm{C}(\mathbf{B}) ; \mathrm{Ba} / \mathrm{Ca}(\mathbf{C})$; and GISP2 $\delta^{18} \mathrm{O}$ record (D) (Stuiver and Grootes, 2000). The blue and yellow blocks indicate the $8.2 \mathrm{ka}$ event and its central vale, respectively. All records are plotted on their respective time scales, in years before $1950 \mathrm{AD}$.

EASM to the $8.2 \mathrm{ka}$ event at high-northern latitude is evident in the Nuanhe Cave. Two internal factors are important for driving EASM circulation: (1) different sensible heat between the tropical Pacific and Asian continent, and (2) latent heat from the tropical Pacific Ocean and released over Asia during precipitation. The weakening EASM will be subdued due to the large thermal inertia in the tropical ocean from which water vapor transport to inner-land over the East Asia.

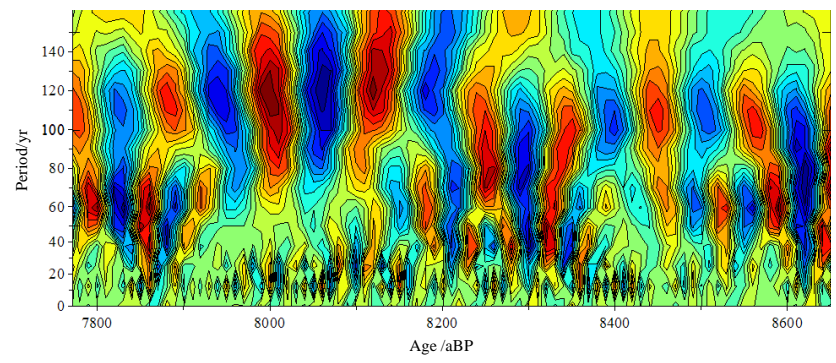

Fig. 7. The time-frequency representation of the real part of complex Morlet wavelet coefficients for decadal-scale periods of the Nuanhe $\delta^{18} \mathrm{O}$ record during $8.6 \sim 7.8 \mathrm{kaBP}$. The method is available at http://atoc.colorado.edu/research/wavelets. X-axis indicates age (a BP), while Y-axis represents the Fourier period (yr). The domain periods are $20 \mathrm{yr}$ and $100 \mathrm{yr}$ over the whole period.

A minor solar minimum coinciding at $\sim 8.2 \mathrm{ka} \mathrm{BP}$ (Muscheler et al., 2004) may have forced the Earth system to cross a threshold and triggered the $8.2 \mathrm{ka}$ event (Bond et al., 2001; Neff et al., 2001; Wang et al., 2005). The excellent correlation between stalagmite $\delta^{18} \mathrm{O}$ record from Hoti cave and tree-ring $\Delta^{14} \mathrm{C}$ record suggests that variations in solar radiation is one of the primary controls on centennialto decadal-scale changes in tropical rainfall and monsoon intensity (Neff et al., 2001). However, our $\delta^{18} \mathrm{O}$ record with annual resolved chronology has a low correlation coefficient $(r=-0.17, n=88)$ with tree-ring $\Delta^{14} \mathrm{C}$. Therefore, the summer monsoon-dominated " $8.2 \mathrm{ka}$ event" cannot be explained in a simple fashion by solar forcing (Cheng et al., 2009). Wavelet analysis on the $\delta^{18} \mathrm{O}$ record of stalagmite NH33 shows two cycles at $\sim 20 \mathrm{yr}$ and $\sim 100 \mathrm{yr}$, respectively (Fig. 7). The two quasi-periodicities are consistent with corresponding oscillations of modern summer rainfall exhibited in northern China (Sun et al., 2002; Ge et al., 2008).

\section{Conclusions}

Decadal-scale variations in $\delta^{18} \mathrm{O}$ records constrained with two annually-laminated stalagmites from the Nuanhe Cave, northeastern China, are well replicated over $8.6 \sim 7.7 \mathrm{ka} \mathrm{BP}$, suggesting that the $\delta^{18} \mathrm{O}$ variability has a climatic origin largely associated with changes in the rainfall $\delta^{18} \mathrm{O}$ from West Pacific during summer seasons. Discrepancy between their contemporaneous growth rates suggests that both the soil $\mathrm{CO}_{2}$ concentration and seepage amount from year to year may alternatively exert a strong influence on stalagmite growth. Thus, our ALT profiles should be calibrated if used as a valid climate indicator. The co-variation of stalagmite $\delta^{18} \mathrm{O}$ profiles indicates that a kinetic effect on $\delta^{18} \mathrm{O}$ value is trivial, although the two samples have a threefold difference in ALT over the contemporaneous intervals. Variations of the $\delta^{13} \mathrm{C}$ and $\mathrm{Ba} / \mathrm{Ca}$ reflect a deteriorated climate initiated at $8.42 \mathrm{ka} \mathrm{BP}$ and centred at $\sim 8.20 \mathrm{ka} \mathrm{BP}$, a copy of the typical 
event at Greenland, suggesting a strong coupling of EAWM and North Atlantic climate. In contrast, the $8.2 \mathrm{ka}$ event is weakly expressed in the summer monsoon-dominated $\delta^{18} \mathrm{O}$ record, indicating that reorganisation of low-latitude atmospheric circulations and hydrological cycles, including different sources of water vapor, transition path and latent heat and so on, may have subdued the signal of the $8.2 \mathrm{ka}$ event around the North Atlantic.

Acknowledgements. This work was supported by grants of National Nature Science Foundation of China (No. 40972111, No. 2007105GZ10033) and the Basic Research Program of Jiangsu Province (No. BK2008025). We would like to thank A. Wackerbarth and K. Holmgren for their constructive comments.

Edited by: A. Mangini

\section{References}

Alley, R. B. and Ágústsdóttir, A. M.: The 8k event: cause and consequences of a major Holocene abrupt climate change, Quaternary Sci. Rev., 24, 1123-1149, 2005.

Alley, R. B., Mayewski, P. A., Sowers, T., Stuiver, M., Taylor, K. C., and Clark, P. U.: Holocene climate instability: A prominent, widespread event 8200 yr ago, Geology, 25, 483-486, 1997.

An, Z.: The history and variability of the East Asian paleomonsoon climate, Quaternary Sci. Rev., 19, 171-187, 2000.

Ayalon, A., Bar-Matthews, M., and Kaufman, A.: Petrography, strontium, barium and uranium concentrations, and strontium and uranium isotope ratios in speleothems as palaeoclimatic proxies: Soreq Cave, Israel, The Holocene, 9, 715-722, 1999.

Baker, A., Smart, P. L., and Ford, D. C.: Northwest European paleoclimate as indicated by growth frequency variations of secondary calcite deposits, Palaeogeogr. Palaeocl., 100, 291-301, 1993.

Baker, A., Genty, D., Dreybrodt, W., Barnes, W. L., Mockler, N. J., and Grapes, J.: Testing theoretically predicted stalagmite growth rate with recent annually laminated samples: Implications for past stalagmite deposition, Geochim. Cosmochim. Acta, 62, 393-404, 1998.

Baker, A., Asrat, A., Fairchild, I. J., Leng, M. J., Wynn, P. M., Bryant, C., Genty, D., and Umer, M.: Analysis of the climate signal contained within $\delta^{18} \mathrm{O}$ and growth rate parameters in two Ethiopian stalagmites, Geochim. Cosmochim. Acta, 71, 29752988, 2007.

Baker, A., Fuller, L., Genty, D., Fairchild, I. J., Jex, C., and Smith, C. L., Annually laminated stalagmites: a review, Int. J. Speleol., 37, 193-206, 2008.

Barber, D. C., Dyke, A., Hillaire-Marcel, C., Jennings, A. E., Andrews, J. T., Kerwin, M. W., Bilodeau, G., McNeely, R., Southon, J., Morehead, M. D., and Gagnon, J. M.: Forcing of the cold event of 8,200 years ago by catastrophic drainage of Laurentide Lakes, Nature, 400, 344-348, 1999.

Bond, G., Kromer, B., Beer, J., Muscheler, R., Evans, M. N., Showers, W., Hoffmann, S., Lotti-Bond, R., Hajdas, I., and Bonani, G.: Persistent solar influence on North Atlantic climate during the Holocene, Science, 294, 2130-2136, 2001.
Burns, S. J., Fleitmann, D., Mudelsee, M., Neff, U., Matter, A., and Mangini, A.: A 780-year annually resolved record of Indian Ocean monsoon precipitation from a speleothem from south Oman, J. Geophys. Res., 107, 4434, doi:10.1029/2001JD001281, 2002.

Cheng, H., Edwards, R. L., Wang, Y. J., Kong, X. G., Ming, Y. F., Gallup, C. D., Kelly, M. J., Wang, X. F., and Liu, W. G.: A penultimate glacial monsoon record from Hulu Cave and two-phase glacial terminations, Geology, 34, 217-220, 2006.

Cheng, H., Fleitmann, D., Edwards, R. L., Wang, X. F., Cruz, F. W., Auler, A. S., Mangini, A., Wang, Y. J., Kong, X. G., Burns, S. J., and Matter, A.: Timing and structure of the $8.2 \mathrm{kyr}$ BP event inferred from $\delta^{18} \mathrm{O}$ records of stalagmites from China, Oman, and Brazil, Geology, 37, 1007-1010, 2009.

Desmarchelier, J. A., Hellstrom, J. C., and McCulloch, M. T.: Rapid trace element analysis of speleothems by ELA-ICP-MS, Chem. Geol., 31, 102-117, 2006.

Ding, Y. H. and Chan, J. C. L.: The East Asian summer monsoon: an overview, Meteorol. Atoms. Phys., 89, 117-142, 2005.

Dorale, J. A. and Liu, Z. H.: Limitations of Hendy test criteria in judging the paleoclimatic suitability of speleothems and the need for replication, J. Cave Karst Stud., 71, 73-80, 2009.

Dreybrodt, W.: Evolution of the isotopic composition of carbon and oxygen in a calcite precipitating $\mathrm{H}_{2} \mathrm{O}-\mathrm{CO}_{2}-\mathrm{CaCO}_{3}$ solution and the related isotopic composition of calcite in stalagmites, Geochim. Cosmochim. Acta., 72, 4712-4724, 2008.

Dulinski, M. and Rozanski, K.: Formation of ${ }^{13} \mathrm{C} /{ }^{12} \mathrm{C}$ isotope ratios in speleothems: a semi-dynamic model, Radiocarbon, 32, 7-16, 1990.

Fairchild, I. J. and Treble, P. C.: Trace elements in speleothems as recorders of environmental change, Quaternary Sci. Rev., 28, 449-468, 2009.

Fairchild, I. J., Smith, C. L., Baker, A., Fuller, L., Spötl, C., Mattey, D., McDermott, F., and E. I. M. F.: Modification and preservation of environmental signals in speleothems, Earth-Sci. Rev., 75, 105-153, 2006.

Fleitmann, D., Burns, S. J., Mudelsee, M., Neff, U., Kramers, J., Mangini, A., and Matter, A.: Holocene Forcing of the Indian Monsoon recorded in a stalagmite from Southern Oman, Science, 300, 1737-1739, 2003.

Gasse, F.: Hydrological changes in the African tropics since the last glacial maximum, Quaternary Sci. Rev., 19, 189-211, 2000.

Ge, Q. S., Guo, X. F., Zheng, J. Y., and Hao, Z. X.: Meiyu in the middle and lower reaches of the Yangtze River since 1736, Chinese Sci. Bull., 53, 107-114, 2008.

Genty, D. and Quinif, Y.: Annually laminated sequences in the internal structure of some Belgian stalagmites-Importance for paleoclimatology, J. Sediment Res., 66, 275-288, 1996.

Genty, D., Blamart, D., Ghaleb, B., Plagnes, V., Causs, Ch., Bakalowicz, M., Zouari, K., Chkir, N., Hellstrom, J., Wainer, K., and Bourges, F.: Timing and dynamics of the last deglaciation from European and North African $\delta^{13} \mathrm{C}$ stalagmite Carbon isotope exchange processes in dynamic caves 399 profilescomparisons with Chinese and South Hemisphere stalagmites, Quaternary Sci. Rev., 25, 2118-2142, 2006.

Haug, G. H., Hughen, K. A., Peterson, L. C., Sigman, D. M., Peterson, L. C., and Rohl, U.: Southward migration of the Intertropical Convergence Zone through the Holocene, Science, 293, 1304 1308, 2001. 
Hellstrom, J. C. and McCulloch, M. T.: Multi-proxy constraints on the climatic significance of trace element records from a New Zealand speleothem, Earth Planet. Sc. Lett., 179, 287-297, 2000.

Hughen, K. A., Overpeck, J. T., Peterson, L. C., and Trumbore, S.: Rapid climate changes in the tropical Atlantic region during the last deglaciation, Nature, 380, 51-54, 1996.

Johnson, K. R., Hu, C., Belshaw, N. S., and Henderson, G. M.: Seasonal trace-element and stable isotope variations in a Chinese speleothem: the potential for highresolution paleomonsoon reconstruction, Earth Planet. Sci. Lett., 244, 394-407, 2006.

Kleiven, H. F., Kissel, C., Laj, C., Ninnemann, U. C., Richter, T. O., and Cortijo, E.: Reduced North Atlantic Deep Water coeval with the glacial Lake Agassiz freshwater outburst, Science, 319, 60-64, 2008.

Lachniet, M. S., Asmerom, Y., Burns, S. J., Patterson, W. P., Polyak, V. J., and Seltzer, G. O.: Tropical response to the $8200 \mathrm{yr}$ B.P. cold event? Speleothem isotopes indicate a weakened early Holocene monsoon in Costa Rica, Geology, 32, 957-960, 2004.

Lajeunesse, P. and St-Onge, G.: The subglacial origin of the Lake Agassiz-Ojibway final outburst flood, Nat. Geosci., 1, 184-188, 2008.

McBride, M. B. and Homenauth, O. P.: Adsorption of aniline on layer silicate clays and an organic soil, Soil Sci. Soc. Am. J., 58, 347-354, 1994.

Mickler, P. J., Banner, J. L., Stern, L., Asmerom, Y., Edwards, R. L., and Ito, E.: Stable isotope variations in modern tropical speleothems: Evaluating equilibrium vs. kinetic isotope effects, Geochim. Cosmochim. Acta, 68, 4381-4393, 2004.

Mickler, P. J., Stern, L. A., and Banner, J. L.: Large kinetic isotope effects in modern speleothems, Geol. Soc. Am. Bull., 118, 65$81,2006$.

Morrill, C., Overpeck, J. T., and Cole, J. E.: A synthesis of abrupt changes in the Asian summer monsoon since the last deglaciation, The Holocene, 13, 456-476, 2003.

Muscheler, R., Beer, J., and Vonmoos, M.: Causes and timing of the $8200 \mathrm{yr}$ BP event inferredfrom the comparison of the GRIP ${ }^{10} \mathrm{Be}$ and the tree ring $\Delta^{14} \mathrm{C}$ record, Quaternary Sci. Rev., 23, 2105-2115, 2004.

Nagashima, K., Tada, R., Tani, A., Sun, Y., Isozaki, Y., Toyoda, S., and Hasegawa, H.: Millennial-scale oscillations of the westerly jet path during the last glacial period, J. Asian Earth Sci., 40, 1214-1220, 2011.

Neff, U., Burns, S. J., Mangini, A., Mudelsee, M., Fleitmann, D., and Matter, A.: Strong coherence between solar variability and the monsoon in Oman between 9 and 6 kyr ago, Nature, 411, 290-293, 2001.

O’Brien, S. R., Mayewski, P. A., Meeker, L. D., Meese, D. A., Twickler, M. S., and Whitlow, S. I.: Complexity of Holocene climate as reconstructed from a Greenland ice core, Science, 270, 1962-1964, 1995.

O’Neil, J. R., Clayton, R. N., and Mayeda, T. K.: Oxygen isotope fractionation in divalent metal carbonates, J. Chem. Phys., 51, 5547-5558, 1969

Paulsen, D. E., Li, H. C., and Ku, T. L.: Climate variability in central China over the last 1270 years revealed by high-resolution stalagmite records, Quaternary Sci. Rev., 22, 691-701, 2003.

Pausata, F. S. R., David, S., Nisancioglu, K. H., and Mbitz, C.: Chinese stalagmite $\delta^{18} \mathrm{O}$ controlled by changes in the Indian monsoon during a simulated Heinrich event, Nat. Geosci., 4,
474-480, 2011.

Proctor, C. J., Baker, A., and Barnes, W. L.: A three thousand year record of North Atlantic climate, Clim. Dynam., 19, 449-454, 2002.

Rohling, E. J. and Pälike, H.: Centennial-scale climate cooling with a sudden cold event around 8,200 years ago, Nature, 434, 975979, 2005.

Scholz, D., Mühlinghaus, C., and Mangini, A.: Modelling the evolution of $\delta^{13} \mathrm{C}$ and $\delta^{18} \mathrm{O}$ in the solution layer on stalagmite surfaces, Geochim. Cosmochim. Acta., 73, 2592-2602, 2009.

Shen, C. C., Edwards, R. L., Cheng, H., Dorale, J. A., Thomas, R. B., Moran, S. B., Weinstein, S., and Edmonds, H. N.: Uranium and thorium isotopic and concentration measurements by magnetic sector inductively coupled plasma mass spectrometry, Chem. Geol., 185, 165-178, 2002.

Stuiver, M. and Grootes, P. M.: GISP2 Oxygen Isotope Ratios, Quaternary Res., 53, 277-284, 2000.

Sun, L., An, G., Ding, L., and Shen, B.: A climatic analysis of summer precipitation features and anomaly in northeast China, Acta Meteor. Sinica, 58, 70-82, 2002.

Sun, Y. B., Clemens, S. C., Morrill, C., Lin, X. P., Wang, X. L., and An, Z, S.: An influence of Atlantic meridional overturning circulation on the East Asian winter monsoon, Nat. Geosci., 5, 46-49, 2012.

Tan, M., Liu, D. S., Hou, J., Qin, X. G., Zhang, H., and Li, T. Y.: Cyclic rapid warming on centennial-scale revealed by a $2650-$ year stalagmite record of warm season temperature, Geophys. Res. Lett., 30, 1617-1621, 2003.

Tan, M., Baker, A., Genty, D., Smith, C., Esper, J., and Cai, B.: Applications of stalagmite laminae to paleoclimate reconstructions: comparison with dendrochronology/climatology, Quaternary Sci. Rev., 25, 2103-2117, 2006.

Thomas, E. R., Wolff, E. W., Mulvaney, R., and Steffensen, J. P.: The 8.2 ka event from Greenland ice cores, Quaternary Sci. Rev., 26, 70-81, 2007.

Thompson, L. G., Mosley-Thompson, E., Davis, M. E., Henderson, K. A., Brecher, H. H., Zagorodnov, V. S., Mashiotta, T. A., Lin, P. N., Mikhalenko, V. N., Hardy, D. R., and Beer, J.: Kilimanjaro ice core records: evidence of Holocene climate changein Tropical Africa, Science, 298, 589-593, 2002.

Treble, P., Shelley, J. M. G., and Chappell, J.: Comparison of high resolution sub-annual records of trace elements in a modern (1911-1992) speleothem with instrumental climate data from southwest Australia, Earth Planet. Sc. Lett., 216, 141-153, 2003.

Wang, Y. J., Cheng, H., Edwards, R. L., An, Z. S., Wu, J. Y., Shen, C. C., and Dorale, J. A.: A high-resolution absolute-dated late Pleistocene monsoon record from Hulu Cave, China, Science, 294, 2345-2348, 2001.

Wang, Y. J., Cheng, H., Edwards, R. L., He, Y. Q., Kong, X. G., An Z. S., Wu, J. Y., Kelly, M. J., Dykoski, K. A., and Li, X. D.: The Holocene Asian Monsoon: links to solar changes and North Atlantic climate, Science, 308, 854-857, 2005.

Wang, Y. J., Cheng, H., Edwards, R. L., Kong, X. G., Shao, X. H., Chen, S. T., Wu, J. Y., Jiang, X. Y., Wang, X. F., and An, Z. S.: Millennial- and orbital-scale changes in the East Asian monsoon over the past 224,000 years, Nature, 451, 1090-1093, 2008.

Wu, J. Y., Shao, X. H., Kong, X. G., and Wang, Y. J.: Imprint of solar activity on Nanjing stalagmite annual layer thickness sequence during the Last Glacial Maximum, Chinese Sci. Bull., 
51, 441-447, 2006.

Wu, L., Li, C., and Yang, C.: Global teleconnections in response to a shutdown of the Atlantic meridional overturning circulation, J. Climate, 21, 3002-3019, 2008.

Yanase, W. and Abe-Ouchi, A.: The LGM surface climate and atmospheric circulation over East Asia and the North Pacific in the PMIP2 coupled model simulations, Clim. Past, 3, 439-451, doi:10.5194/cp-3-439-2007, 2007.

Zhang, R. and Delworth, D. L.: Simulated tropical response to a substantial weakening of the Atlantic thermohaline circulation, J. Climate, 18, 1853-1860, 2005. 